\title{
Strontium Substituted SmNiO3: Novel Electrode Materials for Alkaline Water Electrolysis
}

\author{
Reena Parihar, Priya Sharma, Amritpal Singh Chaddha, Narendra Kumar Singh* \\ Department of Chemistry, Faculty of Science, University of Lucknow, Lucknow-226007 (INDIA) \\ *Corresponding Author Email: nksbhu@yahoo.com, singh_narendra@lkouniv.ac.in, ORCID: 0000-0002-9108-6545 \\ Mob: +91-9451949105
}

\begin{tabular}{l}
\hline https://doi.org/10.14447/jnmes.v24i3.a08 \\
\hline Received: May 15-2021 \\
Accepted: August 10-2021 \\
\hline
\end{tabular}

Keywords: Samarium nickelates, sol-gel method, XRD, oxygen evolution, thermodynamic parameters

\begin{abstract}
Sr-substituted $\mathrm{SmNiO}_{3}$ perovskite-type oxides have been investigated for their electrocatalytic properties towards oxygen evolution reaction (OER) in alkaline medium. Materials were obtained by using low temperature malic acid sol-gel route. To know the redox behaviour, electrocatalytic activity and thermodynamic parameters of oxides, cyclic voltammetry $(\mathrm{CV})$ and anodic polarization curve (Tafel plot) were recorded in $1 \mathrm{M} \mathrm{KOH}$ at $25^{\circ} \mathrm{C}$. X-ray diffraction (XRD) study indicates the formation of almost pure perovskite phase of the material. A pair of redox peaks was observed (anodic; $\mathrm{Ep}_{\mathrm{a}}=494 \pm 12 \mathrm{mV}$ and corresponding cathodic; $\mathrm{Ep}_{\mathrm{c}}=360 \pm 4 \mathrm{mV}$ ) in the potential region 0.0-0.7 V prior to onset of OER. As observed in the case of La-based perovskite oxides, $\mathrm{Sr}$-substitutions in the $\mathrm{SmNiO}_{3}$ also enhance the electrocatalytic properties of the material. However, Sm-based oxides showed least electrocatalytic activity as compared to La-based oxides. The estimated values of Tafel slope and reaction order indicate that each oxide electrode, except $\mathrm{SmNiO}_{3}$, follows similar mechanistic path towards OER. Standard entropy of activation $\left(\Delta S^{\circ \#}\right)$, standard enthalpy of activation $\left(\Delta H^{\circ \#}\right)$ and standard electrochemical energy of activation $\left(\Delta \mathrm{H}_{\mathrm{el}}{ }^{\circ}\right)$ was determined by recording the anodic polarization curve in $1 \mathrm{M} \mathrm{KOH}$ at different temperatures.
\end{abstract}

\section{INTRODUCTION}

Perovskite-type mixed oxides of lanthanum having composition $\mathrm{La}_{1-\mathrm{x}} \mathrm{M}_{\mathrm{x}} \mathrm{M}^{\prime} \mathrm{O}_{3}$ (where, $\mathrm{M}=\mathrm{Sr}, \mathrm{Pb}, \mathrm{Cu}, \mathrm{Cr} ; \mathrm{M}^{\prime}=$ $\mathrm{Co}, \mathrm{Mn}, \mathrm{Ni}$ and $0.0 \leq \mathrm{x} \leq 0.8$ ) are considered as very promising materials and have been extensively studied for oxygen evolution/reduction reaction [1-30]. These materials have several technological applications $[1,31,32]$. There are several methods employed to synthesize these oxides. These include, high temperature solid state reaction and thermal decomposition methods [33-38], which generally produced oxides with low specific surface area and reduced homogeneity and low temperature methods [39-43] in which amorphous organic acids, like malic acid (MA), citric acid (CA), polyacrylic acid (PAA), citric acid-ethylene diamine (CA-EDA), polyvinylpyrrolidone (PVP) etc are used as precursors. These low temperature methods facilitate to provide homogeneity in the metal ions and produced oxides with high specific surface area and therefore improved electrochemical properties.

Recently, Azad et al. [44] reported oxygen evolution electrocatalytic properties of some perovskite mixed oxides as bifunctional electrocatalysts with current density $10 \mathrm{~mA} \mathrm{~cm}^{-2}$ at $\mathrm{E}=1.65 \mathrm{~V}$ vs RHE. Sczancoski et al. [45] developed Fedoped $\mathrm{LaNiO}_{3}$ electrocatalysts for OER studies at deposited pyrolytic graphite sheets and found highest activity with $\mathrm{LaNi}_{0.4} \mathrm{Fe}_{0.6} \mathrm{O}_{3}$ having Tafel slope value of $52 \mathrm{mV}$ decade ${ }^{-1}$. Findings of these literatures revealed that the metal ios have vital role in the enhancement of physical and electrocatalytic properties of materials. Further, it has been observed that most of the OER studies have been carried out with La-based perovskite oxides. Sm-based perovskites are very little investigated with regards to oxygen evolution/reduction reaction.

Shao-Horn et al. [46] used elements of lanthanide series instead of lanthanum and prepared double perovskites $\left(\mathrm{Ln}_{0.5} \mathrm{Ba}_{0.5}\right) \mathrm{CoO}_{3-\delta}(\mathrm{Ln}=\mathrm{Pr}, \mathrm{Sm}, \mathrm{Gd}$ and $\mathrm{Ho})$ by adopting thermal decomposition method. They observed better electrocatalytic activity towards oxygen evolution reaction in alkaline solution. Very recently [27], we found better results towards OER with partial substitution of $\mathrm{Sm}$ for $\mathrm{Sr}$ in $\mathrm{La}_{0.4} \mathrm{Sr}_{0.6} \mathrm{CoO}_{3}$.

In view of the above, we extended our research and used Sm-element instead of La to obtain perovskite-type oxides and further studied their electrocatalytic properties for OER in alkaline medium. Results, so obtained, are described in this paper.

\section{EXPERIMENTAL}

Strontium substituted $\mathrm{SmNiO}_{3}$ having compositions $\mathrm{Sm}_{1}$ ${ }_{x} \mathrm{Sr}_{\mathrm{x}} \mathrm{NiO}_{3}(0 \leq \mathrm{x} \leq 0.8)$ were prepared by adopting the method reported by Teraoka et al. [41]. In each preparation, all the reagents and chemicals were taken in purified form. The stoichiometric amount of metal nitrates and excess amount of malic acid were dissolved in $500 \mathrm{ml}$ double distilled. $35 \%$ 
ammonia solution was used to maintain the $\mathrm{pH}$ of mixture 3.5 , which then concentrated over a water bath at $60-70^{\circ} \mathrm{C}$. A gel like mass was obtained which decomposed and sintered at $600^{\circ} \mathrm{C}$ for $5 \mathrm{~h}$ to get the desired oxide material. Techniques like, X-ray diffractometer ( Philips and Panalytical Powder XRay Diffractometer) provided with radiation source $\mathrm{Cu}-\mathrm{K} \alpha(\lambda$ $=1.54056 \AA$ ) and Scanning Electron Microscope (JEOL, JSM 6490) were used to determine the phase and morphology of the materials. The crystallite size of the material was calculated by using Scherer's formula.

The electrocatalytic property of the material was determined in the form of oxide film electrode on pre-treated $\mathrm{Ni}$-support. The procedure adopted for the treatment of Nisupport, preparation of oxide film and electrical contact was same as described elsewhere $[9,15]$. During experiment, the oxide film electrode was used as working electrode. $\mathrm{Hg} / \mathrm{HgO}$ $/ 1 \mathrm{M} \mathrm{KOH}$ and Pt-foil were used as reference and auxiliary electrode, respectively. A three-electrode single compartment glass cell, which is connected to the potentiostat/galvanostat (Gamry Reference 600 ZRA) and corrosion and physical electrochemical software compiled personal computer, was used for the electrochemical studies. In order to minimise the additional potential drop, the reference electrode was connected electrically to the electrolyte $(1 \mathrm{M} \mathrm{KOH})$ via a Luggin capillary ( $\mathrm{KCl} /$ Agar-Agar salt bridge).

\section{RESULTS AND DISCUSSION 3.1 X-Ray Diffraction (XRD)}

X-ray diffraction (XRD) patterns of oxide powders, $\mathrm{Sm}_{0.2} \mathrm{Sr}_{0.8} \mathrm{NiO}_{3}$ and $\mathrm{Sm}_{0.6} \mathrm{Sr}_{0.4} \mathrm{NiO}_{3}$, sintered at $600{ }^{\circ} \mathrm{C}$ for $5 \mathrm{~h}$ and recorded between $2 \theta=20^{\circ}$ to $100^{\circ}$ are shown in Fig. 1 . The observed patterns indicates the formation of almost perovskite phase of the material and found to be very similar to those with $\mathrm{Sm}$-substituted $\mathrm{La}(\mathrm{Sr}) \mathrm{CoO}_{3}$ [27] obtained by PVP method, which followed hexagonal crystal geometry of respective JCPDS ASTM file 25-1060. The crystallite size was calculated by using Scherer's formula [47] and found to be $\sim 30$ and $\sim 40 \mathrm{~nm}$ for $\mathrm{Sm}_{0.2} \mathrm{Sr}_{0.8} \mathrm{NiO}_{3}$ and $\mathrm{Sm}_{0.6} \mathrm{Sr}_{0.4} \mathrm{NiO}_{3}$, repesctvely.

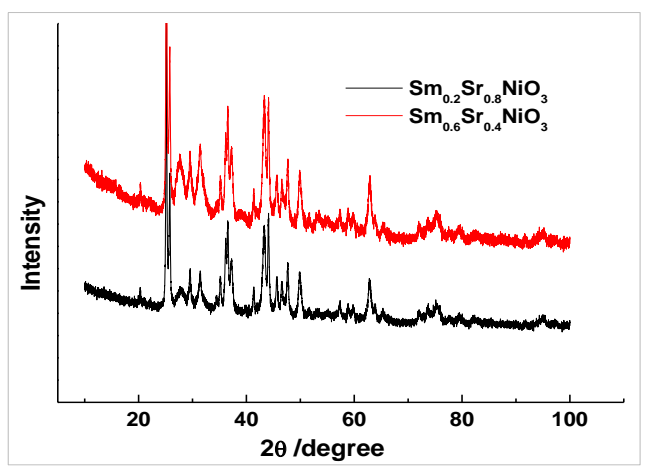

Figure 1: XRD powder patterns of oxides sintered at $600^{\circ} \mathrm{C}$ for $5 \mathrm{~h}$

\subsection{Scanning Electron Micrograph (SEM)}

Figure 2 represents the SE-micrograph of sintered $\left(600^{\circ} \mathrm{C}\right.$ for $5 \mathrm{hrs}) \mathrm{SmNiO}_{3}$ and $\mathrm{Sm}_{0.2} \mathrm{Sr}_{0.8} \mathrm{NiO}_{3}$ oxide powder at the magnification $\times 200$. Morphological appearance of both oxides are seemed to be similar and showed nebulous structure. Some small pores has also been observed in the oxide matrix.
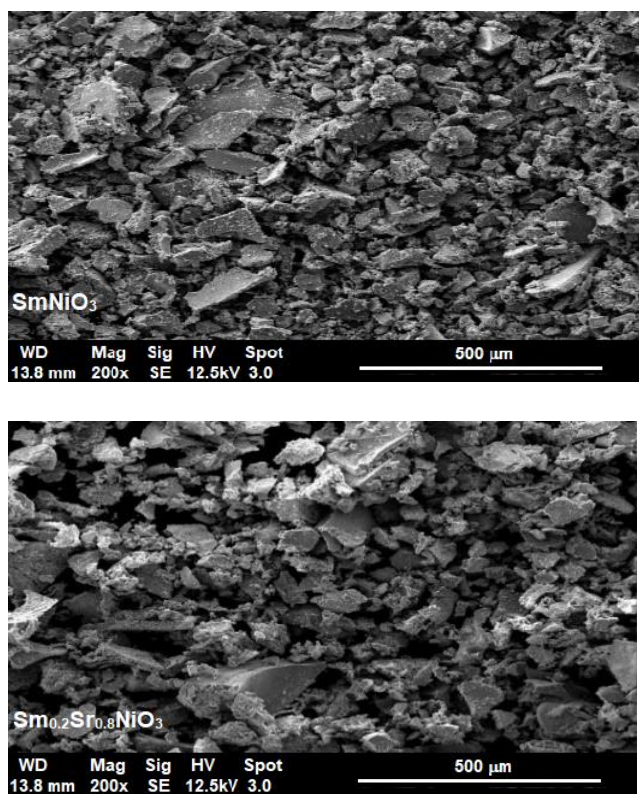

Figure 2: SE Micrographs of oxide powder sintered at $600^{\circ} \mathrm{C}$ for $5 \mathrm{hrs}$.

\subsection{Cyclic Voltammetry (CV)}

Figure 3 represents cyclic voltammogram of the oxide film electrode on Ni-substrate between potential region $0.0-0.7 \mathrm{~V}$ in $1 \mathrm{M} \mathrm{KOH}$ at $25^{\circ} \mathrm{C}$ (scan rate $=20 \mathrm{mVsec}^{-1}$ ). Each voltammogram revealed a pair of redox peak, an anodic $\left(\mathrm{Ep}_{\mathrm{a}}\right.$ $=494 \pm 12 \mathrm{mV})$ and corresponding cathodic $\left(\mathrm{Ep}_{\mathrm{c}}=360 \pm 4\right.$ $\mathrm{mV}$ ), prior to the onset of oxygen evolution reaction. The peak potential values of each voltammetric curve (Table 1) corresponds to that obtained with the bare Ni [48]. Further, the $\mathrm{CV}$ of the oxide on Pt-substrates did not exhibit any redox peaks under similar experimental conditions. This specifies that the redox peaks might be due to the oxidation-reduction of Ni-substrate, which comes into contact with electrolyte during the cycle process through pores, cracks and grain boundaries. Aslo, it has been reported [49] that perovskite oxides prepared at low temperature are highly hygroscopic and may undergo hydration in electrolytic solution. 


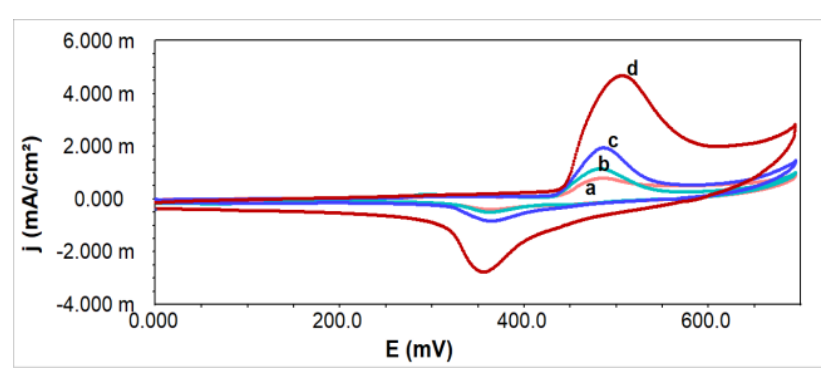

Figure 3: Cyclic voltammograms of $\mathrm{Ni} / \mathrm{Sm} 1-\mathrm{xSrxCoO} 3(0$ $\leq \mathrm{x} \leq 0.8)$ in $1 \mathrm{M} \mathrm{KOH}$ at $25^{\circ} \mathrm{C}$; (scan rate $\left.=20 \mathrm{mV} \mathrm{sec}^{-1}\right)$; a:

$\mathrm{SmNiO}_{3}$, b: $\mathrm{Sm}_{0.8} \mathrm{Sr}_{0.2} \mathrm{NiO}_{3}, \mathrm{c}: \mathrm{Sm}_{0.6} \mathrm{Sr}_{0.4} \mathrm{NiO}_{3}$, d: $\mathrm{Sm}_{0.2} \mathrm{Sr}_{0.8} \mathrm{NiO}_{3}$

Other voltammetric constituents, such as peak separation potential $\left(\Delta \mathrm{E}_{\mathrm{p}}=\mathrm{E}_{\mathrm{Pa}}-\mathrm{E}_{\mathrm{Pc}}\right)$, formal redox potentail $\left[\mathrm{E}^{\circ}=\left(\mathrm{E}_{\mathrm{Pa}}-\right.\right.$ $\left.\left.\mathrm{E}_{\mathrm{Pc}}\right) / 2\right]$, anodic and cathodic peak current, volatmmetric charge (q), etc were estimated from the voltammetric curve and listed in Table 1. With exception to $\mathrm{Sm}_{0.2} \mathrm{Sr}_{0.8} \mathrm{NiO}_{3}$, the value of $\Delta \mathrm{E}_{\mathrm{p}}$ was almost same with each oxide electrode. A negligible change in the formal redox potential has been observed with the substitution of $\mathrm{Sr}$ for $\mathrm{Sm}$ in the base oxide $\left(\mathrm{SmNiO}_{3}\right)$. Anodic peak current, cathodic peak current and voltametric charge (q) are increased with increase in concentration of $\mathrm{Sr}$ in the oxide. The value of $\mathrm{q}$ is estimated by integrating the $\mathrm{CV}$ curve from zero to the potential just prior the OER. The ratio of anodic and cathodic peak current is more than unity, indicating the irreversibility [50-52] of the redox process.

Table 1: Values of the cyclic voltammetric parameters of $\mathrm{Ni} /$ $\mathrm{Sm}_{1-\mathrm{x}} \mathrm{Sr}_{\mathrm{x}} \mathrm{NiO}_{3}(0 \leq \mathrm{x} \leq 0.8)$ in $1 \mathrm{M} \mathrm{KOH}$ at $25{ }^{\circ} \mathrm{C}$ (scan rate $=$ $20 \mathrm{mV} \mathrm{sec}{ }^{-1}$ )

\begin{tabular}{|l|c|c|c|c|c|c|c|c|}
\hline Electrode & $\begin{array}{c}\mathrm{E}_{\mathrm{Pa}} \\
/ \mathrm{mV}\end{array}$ & $\begin{array}{c}\mathrm{E}_{\mathrm{Pc}} \\
/ \mathrm{mV}\end{array}$ & $\begin{array}{l}\Delta \mathrm{E}_{\mathrm{p}} \\
/ \mathrm{mV}\end{array}$ & $\begin{array}{c}\mathrm{E}^{\circ} \\
\mathrm{mV}\end{array}$ & $\begin{array}{l}\left|\mathrm{j}_{\mathrm{p}_{\mathrm{a}}}\right| \\
/ \mathrm{mA} \\
\mathrm{cm}^{-2}\end{array} \mid \begin{array}{l}\left|\mathrm{j}_{\mathrm{p}_{\mathrm{c}}}\right| \\
/ \mathrm{mA} \\
\mathrm{cm}^{-2}\end{array}$ & $\frac{\left|\mathrm{j}_{\mathrm{p}_{\mathrm{a}}}\right|}{\left|\mathrm{j}_{\mathrm{p}_{\mathrm{c}}}\right|}$ & $\begin{array}{c}\mathrm{q} \\
/ \mathrm{mC} \\
\mathrm{cm}\end{array}$ \\
\hline $\mathrm{SmNiO}_{3}$ & 483 & 360 & 123 & 422 & 0.78 & 0.35 & 2.2 & 1.7 \\
\hline $\mathrm{Sm}_{0.8} \mathrm{Sr}_{0.2} \mathrm{NiO}_{3}$ & 482 & 362 & 120 & 422 & 1.14 & 0.52 & 2.2 & 2.6 \\
\hline $\mathrm{Sm}_{0.6} \mathrm{Sr}_{0.4} \mathrm{NiO}_{3}$ & 486 & 364 & 122 & 425 & 1.94 & 0.84 & 2.3 & 3.7 \\
\hline $\mathrm{Sm}_{0.2} \mathrm{Sr}_{0.8} \mathrm{NiO}_{3}$ & 506 & 356 & 150 & 431 & 4.69 & 2.77 & 1.7 & 16.0 \\
\hline
\end{tabular}

The effect of scan rate on the redox process has also been studied in $1 \mathrm{M} \mathrm{KOH}$ at $25^{\circ} \mathrm{C}$ and shown in Fig. 4 for the $\mathrm{Ni} / \mathrm{Sm}_{0.2} \mathrm{Sr}_{0.8} \mathrm{NiO}_{3}$. The nature of $\mathrm{CV}$ curve as shown figure 4 is almost similar to that observed at scan rate of $20 \mathrm{mV} \mathrm{sec}^{-1}$. But, a shift in anodic and cathodic peak potential was observed with the increase of scan rates from 20 to $120 \mathrm{mV} \mathrm{sec}^{-1}$.

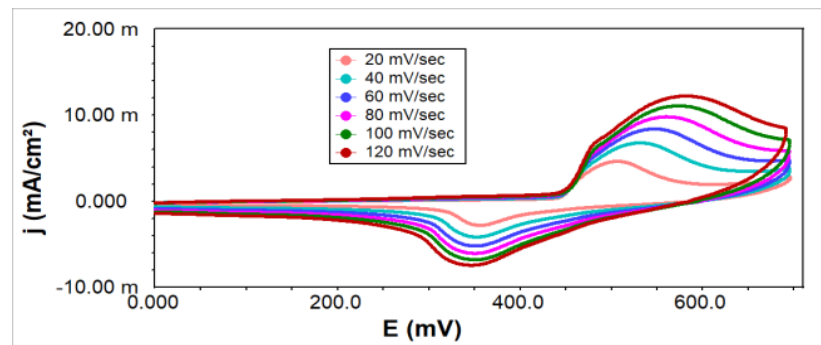

Figure 4: Cyclic voltammogram of $\mathrm{Ni} / \mathrm{Sm}_{0.2} \mathrm{Sr}_{0.8} \mathrm{NiO}_{3}$ film electrode at different scan rates in $1 \mathrm{M} \mathrm{KOH}\left(25^{\circ} \mathrm{C}\right)$
It is found that both anodic and cathodic peak currents increased linearly with increase in the scan rates. The variation is represented in the plot of $\left|j_{P}\right|$ vs square root of scan rate (Fig. 5) for $\mathrm{Sm}_{0.2} \mathrm{Sr}_{0.8} \mathrm{NiO}_{3}$ oxide electrode. The voltammetric charge (q) was also plotted against (scan rate) $)^{-1 / 2}$ and shown in Fig. 6. The straight line obtained indicates that the surface redox behaviour is diffusion controlled [15].

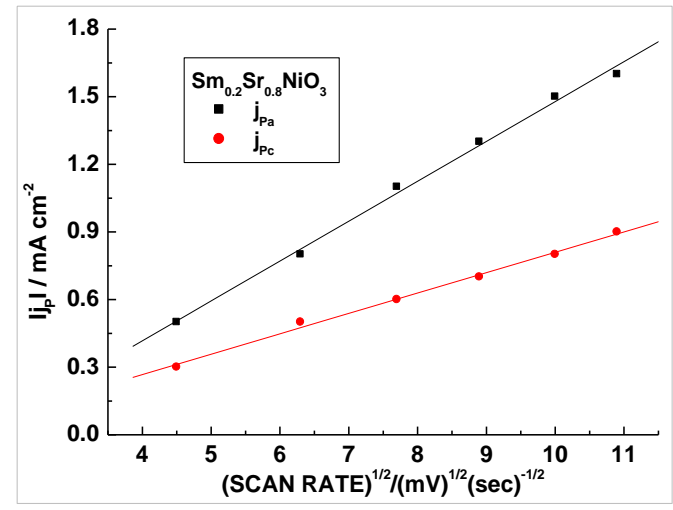

Figure 5: Plot of $\left|j_{\mathrm{P}}\right|$ vs $(\mathrm{scan} \text { rate })^{1 / 2}$ for the oxide film electrode on $\mathrm{Ni}$ in $1 \mathrm{M} \mathrm{KOH}\left(25^{\circ} \mathrm{C}\right)$

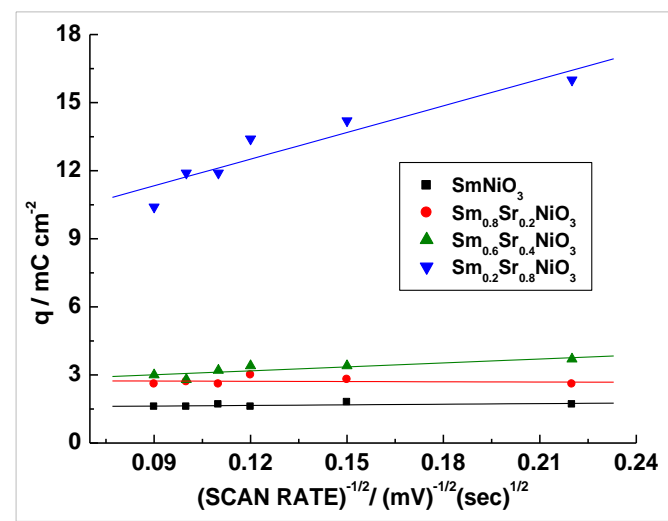

Figure 6: Plot of voltammetric charge (q) vs (scan rate $)^{-1 / 2}$ for the oxide film electrode on $\mathrm{Ni}$ in $1 \mathrm{M} \mathrm{KOH}\left(25^{\circ} \mathrm{C}\right)$

\subsection{Electrocatalytic Activity}

To know the electrocatalytic activity of the oxide electrocatalyst, iR-compensated anodic polarization curves (E vs.log j) was recorded in $1 \mathrm{M} \mathrm{KOH}$ at $25{ }^{\circ} \mathrm{C}$. The polarization curve, so obtained is shown in Fig. 7. The Tafel slope values as well as the electrocatalytic activity in terms of potential and current density were estimated from the polarization curve and listed in Table 2.. The Tafel slope value were ranged between 111-118 mVdecade ${ }^{-1}$. On the comparison of electrocatalytic activity in terms of current density at fixed potential of 800 $\mathrm{mV}$, it is observed that a slight increase in the electrocatalytic activity has been found with Sr-substitution. The activity being maximum with $0.8 \mathrm{~mol} \mathrm{Sr-substitution}$. 


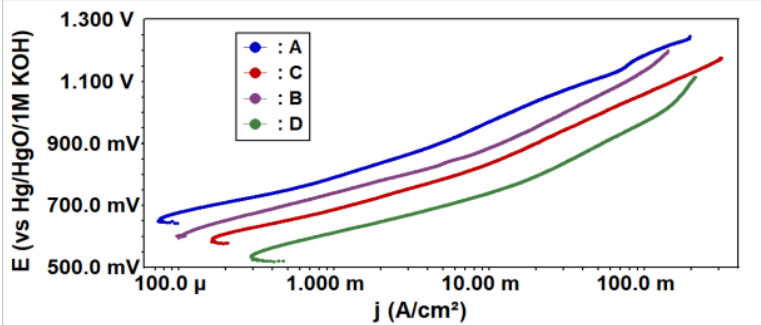

Figure 7: Tafel plots for oxygen evolution on $\mathrm{Ni} / \mathrm{Sm}_{1-}$ ${ }_{x} \mathrm{Sr}_{\mathrm{x}} \mathrm{NiO}_{3}(0 \leq \mathrm{x} \leq 0.8)$ in $1 \mathrm{M} \mathrm{KOH}$ at $25{ }^{\circ} \mathrm{C}$ (scan rate: 0.2 $\left.\mathrm{mVsec}^{-1}\right)$.

A: $\mathrm{SmNiO}_{3}, \mathrm{~B}: \mathrm{Sm}_{0.8} \mathrm{Sr}_{0.2} \mathrm{NiO}_{3}, \mathrm{C}: \mathrm{Sm}_{0.6} \mathrm{Sr}_{0.4} \mathrm{NiO}_{3}$, D: $\mathrm{Sm}_{0.2} \mathrm{Sr}_{0.8} \mathrm{NiO}_{3}$

Table 2: Electrode kinetic parameters for oxygen evolution reaction on $\mathrm{Ni} / \mathrm{Sm}_{1-\mathrm{x}} \mathrm{Sr}_{\mathrm{x}} \mathrm{NiO}_{3}(0 \leq \mathrm{x} \leq 0.8)$ electrodes in $1 \mathrm{M}$ $\mathrm{KOH}$ at $25^{\circ} \mathrm{C}$

\begin{tabular}{|c|c|c|c|c|c|c|}
\hline \multirow[t]{2}{*}{ Electrode } & \multirow[t]{2}{*}{$\begin{array}{c}\text { Tafel } \\
\text { slope } \\
\text { (b) }\end{array}$} & \multirow[t]{2}{*}{$\begin{array}{c}\text { Orde } \\
\mathbf{r} \\
(\mathbf{p})\end{array}$} & \multicolumn{2}{|c|}{$\begin{array}{c}\mathrm{E} / \mathrm{mV} \\
\text { at } \\
\mathbf{j} / \mathrm{mA}^{-2} \mathrm{~cm}^{-2}\end{array}$} & \multicolumn{2}{|c|}{$\begin{array}{c}\mathbf{j} / \mathbf{m A ~} \mathbf{c m}^{-2} \\
\text { at } \\
\mathrm{E} / \mathrm{mV}\end{array}$} \\
\hline & & & 10 & 100 & 700 & 800 \\
\hline $\mathrm{SmNiO}_{3}$ & 118 & 1.9 & 921 & 1134 & 0.5 & 1.1 \\
\hline $\mathrm{Sm}_{0.8} \mathrm{Sr}_{0.2} \mathrm{NiO}_{3}$ & 113 & 1.2 & 849 & 1068 & 0.9 & 1.5 \\
\hline $\mathrm{Sm}_{0.6} \mathrm{Sr}_{0.4} \mathrm{NiO}_{3}$ & 114 & 0.9 & 888 & 1116 & 0.9 & 1.3 \\
\hline $\mathrm{Sm}_{0.2} \mathrm{Sr}_{0.8} \mathrm{NiO}_{3}$ & 111 & 1.0 & 815 & 1045 & 1.2 & 4.1 \\
\hline
\end{tabular}

As per Table 2, oxide electrodes show the following order of electrocatalytic activity at constant potential $(\mathrm{E}=800 \mathrm{mV})$;

$\mathrm{Sm}_{0.2} \mathrm{Sr}_{0.8} \mathrm{NiO}_{3}\left(\mathrm{j}=4.1 \mathrm{~mA} \mathrm{~cm}{ }^{-2}\right)>\mathrm{Sm}_{0.8} \mathrm{Sr}_{0.2} \mathrm{NiO}_{3}(\mathrm{j}=1.5$ $\left.\mathrm{mA} \mathrm{cm}{ }^{-2}\right)>\mathrm{Sm}_{0.6} \mathrm{Sr}_{0.4} \mathrm{NiO}_{3}\left(\mathrm{j}=1.3 \mathrm{~mA} \mathrm{~cm}{ }^{-2}\right)>\mathrm{SmNiO}_{3}(\mathrm{j}=$ $1.1 \mathrm{~mA} \mathrm{~cm}^{-2}$ )

The anodic polarization curve was recorded to determine the reaction order of $\mathrm{OE}$ with each oxide electrode in different $\mathrm{KOH}$ concentraation at $25^{\circ} \mathrm{C}$. During the process, the electrical intensity of the each electrolytic solution was kept uniform. An inert electrolyte $\mathrm{KNO}_{3}$ was used to maintain the ionic strength $(\mu=1.5)$ of each solution constant. A representative polarization curve for $\mathrm{Ni} / \mathrm{Sm}_{0.2} \mathrm{Sr}_{0.8} \mathrm{NiO}_{3}$ is shown in the Fig. 8. From figure, values of current density $\left(\log \mathrm{j} / \mathrm{A} \mathrm{cm}^{-2}\right)$ were estimated at a certain potential and plotted against $\log \left[\mathrm{OH}^{-}\right]$, which is shown in the Fig. 9 at a constant potential of $E=700 \mathrm{mV}$. The order of reaction was calculated by measuring the slope of straight line and values are listed in Table 2. The observed values of Tafel slope and reaction order as given in Table 2 suggest that the OER taking place at the electrocatalysts follows similar mechanistic path except $\mathrm{SmNiO}_{3}$, which has reaction order 1.9 with Tafel slope 118 $\mathrm{mV}$ decade $^{-1}$.

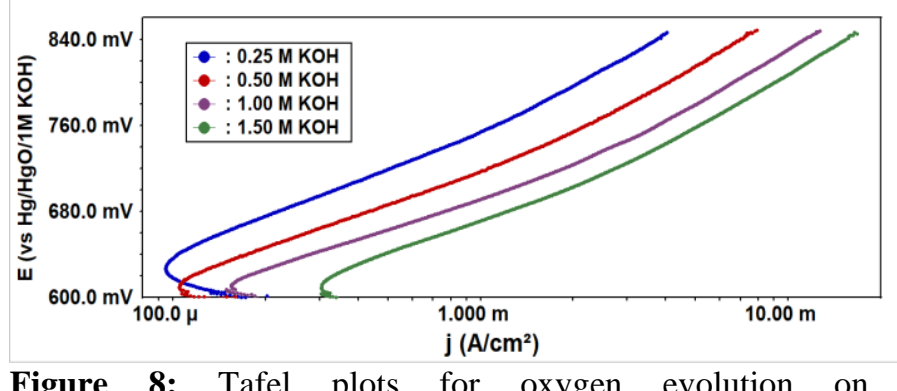

Figure 8: Tafel plots for oxygen evolution on $\mathrm{Ni} / \mathrm{Sm}_{0.2} \mathrm{Sr}_{0.8} \mathrm{NiO}_{3}$ at varying $\mathrm{KOH}$ concentrations $(\mu=1.5)$ at $25{ }^{\circ} \mathrm{C}$

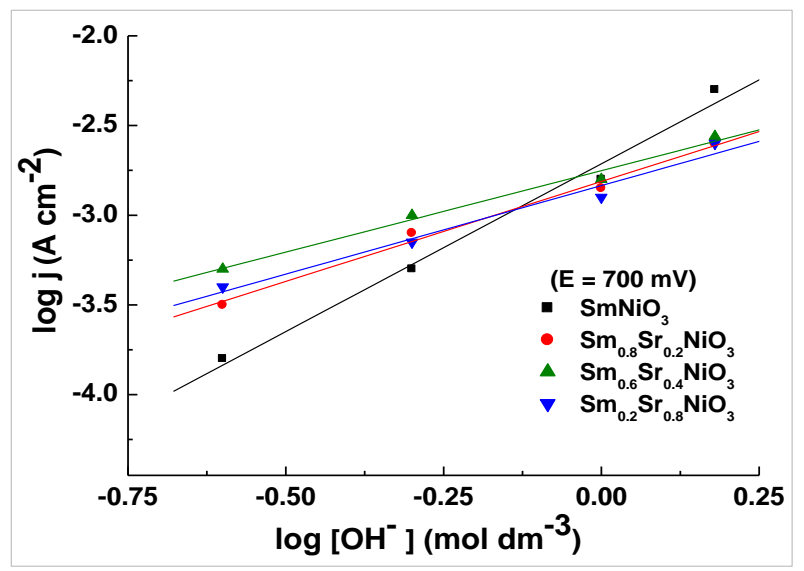

Figure 9: Plot of log j vs $\log \left[\mathrm{OH}^{-}\right]$for $\mathrm{Ni} / \mathrm{Sm}_{1-\mathrm{x}} \mathrm{Sr}_{\mathrm{x}} \mathrm{NiO}_{3}(0 \leq$ $\mathrm{x} \leq 0.8$ ) electrodes.

\subsection{Thermodynamic Parameters}

Thermodynamic parameters of two oxide electrocatalysts towards OER have also been determined by recording the anodic polarization curve in $1 \mathrm{M} \mathrm{KOH}$ at $20,30,40$, and $50^{\circ} \mathrm{C}$. A set of polarization curve for $\mathrm{SmNiO}_{3}$ is shown in Figure 10. During the experiment, the temperature of the reference electrode was kept constant. From figure, values of $\log \mathrm{j}$ (in $\mathrm{mA} \mathrm{cm}{ }^{-2}$ ) were estimated at a constant applied potential and plotted against $1 / \mathrm{T}$. The standard apparent enthalpy of activation $\left(\Delta H_{\mathrm{el}}{ }^{\circ}\right)$ was calculated at a certain potential $(\mathrm{E}=$ $650 \mathrm{mV}$ ) by measuring the slope of Arrhenius plot, $\log \mathrm{j}$ vs $1 / \mathrm{T}$ (Fig. 11).

Further, following two relations (1) and (2) [53] are used to determine the values of standard enthalpy of activation $\left(\Delta \mathrm{H}^{\circ \neq}\right)$ and standard entropy of activation $\left(\Delta \mathrm{S}^{\circ \neq}\right)$, respectively.

$$
\Delta \mathrm{H}_{\mathrm{el}}^{\mathrm{o} \neq}=\Delta \mathrm{H}^{\mathrm{o} \neq}-\alpha \mathrm{F \eta}
$$

$$
\Delta \mathrm{S}^{\mathrm{o} \neq}=2.3 \mathrm{R}\left[\log \mathrm{j}+\frac{\Delta \mathrm{H}_{\mathrm{el}}^{\mathrm{o} \neq}}{2.3 \mathrm{RT}}-\log \left(\mathrm{nF} \omega \mathrm{C}_{\mathrm{OH}^{-}}\right)\right]
$$

In equation (1), $\alpha(=2.303 \mathrm{RT} / \mathrm{bF})$ is the transfer coefficient. $\eta$ is the overpotential equal to $\mathrm{E}-\mathrm{E}_{2} / \mathrm{OH}^{-}$, where $\mathrm{E}$ is the potential applied and $\mathrm{E}_{\mathrm{O} 2} / \mathrm{OH}^{-}(=0.303 \mathrm{~V}$ vs. $\mathrm{Hg} / \mathrm{HgO})$ [54] is the theoretical equilibrium Nernst potential in $1 \mathrm{M}$ $\mathrm{KOH}$ at $25{ }^{\circ} \mathrm{C}$. The Tafel slope (b) is determined from the polarization curves obtained at different temperatures. R, F are the universal constants and $\mathrm{T}$ is the absolute temperature. 
In equation (2), the value of frequency term $(\omega)$ is equal to $k_{\mathrm{B}} T / h . \quad k_{\mathrm{B}}$ and $\mathrm{h}$ are the Boltzmann constant and Planck's constant, respectively. Here, the value of ' $n$ ' was taken 2 in every calculation. The calculated values of thermodynamic parameters are listed in the Table 3. Values of electrochemical activation energy were found to be 47.5 and $54.9 \mathrm{~kJ} \mathrm{~mol}^{-1}$ for $\mathrm{SmNiO}_{3}$ and $\mathrm{Sm}_{0.8} \mathrm{Sr}_{0.2} \mathrm{NiO}_{3}$, respectively.

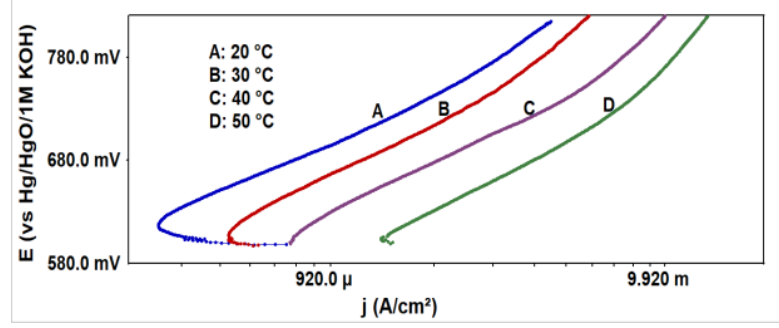

Figure 10: Anodic polarization curve for the $\mathrm{SmNiO}_{3}$ film electrode on $\mathrm{Ni}$ at different temperatures in $1 \mathrm{M} \mathrm{KOH}$

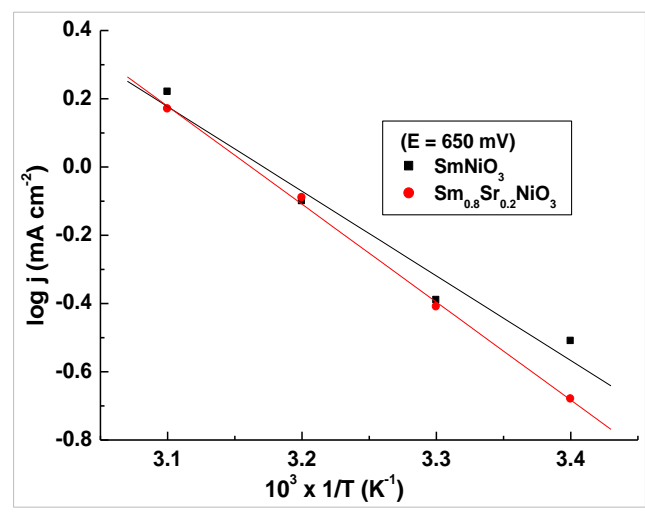

Figure 11: The Arrhenius plot at a constant applied potential $(650 \mathrm{mV})$ for La1-xSrxCoO3 $(\mathrm{x}=0$ and 0.2$)$ in $1 \mathrm{M} \mathrm{KOH}$

Table 3: Thermodynamic parameters for $\mathrm{O}_{2}$ evolution on $\mathrm{Ni} / \mathrm{Sm}_{1-\mathrm{x}} \mathrm{Sr}_{\mathrm{x}} \mathrm{NiO}_{3}(\mathrm{x}=0$ and 0.2$)$ in $1 \mathrm{M} \mathrm{KOH}$

\begin{tabular}{|l|c|c|c|c|}
\hline Electrode & $\begin{array}{c}\Delta \mathrm{H}_{\mathrm{el}}{ }^{\circ \#}(\mathrm{~kJ} \\
\left.\mathrm{mol}^{-1}\right)\end{array}$ & $\begin{array}{c}-\Delta \mathrm{S}^{\circ \#} \\
\left(\mathrm{Jdeg}^{-1}\right. \\
\left.\mathrm{mol}^{-1}\right)\end{array}$ & $\alpha$ & $\begin{array}{c}\Delta \mathrm{H}^{\text {o\# }} \\
\left(\mathrm{kJ} \mathrm{mol}^{-}\right. \\
1)\end{array}$ \\
\hline $\mathrm{SmNiO}_{3}$ & 47.5 & 195.1 & 0.5 & 64.4 \\
\hline $\mathrm{Sm}_{0.8} \mathrm{Sr}_{0.2} \mathrm{NiO}_{3}$ & 54.9 & 171.9 & 0.5 & 71.5 \\
\hline
\end{tabular}

\section{CONCLUSION}

The present work has been undertaken to study the electrocatalytic properties of Sm-based perovskite over Labased. Sr-substitution in the base oxide increased the electrocatalytic properties of the material. But, this increase is not so significant as observed in the case of La-based perovkites. As per present study, Sm-based perovskites are not prolific electrocatalysts for the electrolysis point of view.

\section{ACKNOWLEDGEMENTS}

Authors are thankful to SERB (DST), New Delhi for providing electrochemical impedance system under Fast Track Scheme for Young Scientist (No.: SR/FT/CS-044/2009).
Thanks are also given to BSIP and Department of Chemistry, University of Lucknow for SEM and basic infrastructure, respectively.

\section{REFERENCES}

1. Meadocroft D. B. (1970). Low-cost oxygen electrode material, Nature, 226:847-848. https://doi.org/10.1038/ $226847 \mathrm{a} 0$.

2. Matsumoto Y., Sato E. (1979). Oxygen evolution on $\mathrm{La}_{1-\mathrm{x}} \mathrm{Sr}_{\mathrm{x}} \mathrm{MnO}_{3}$ electrodes in alkaline solutions, Electrochim. Acta, 24:421-423. https://doi.org/10.1016 /0013-4686(79)87030-9.

3. Matsumoto Y., Yamada S., Nishida T., Sato E. (1980). Oxygen evolution on $\mathrm{La}_{1-\mathrm{x}} \mathrm{Sr}_{\mathrm{x}} \mathrm{Fe}_{1-\mathrm{y}} \mathrm{Co}_{\mathrm{y}} \mathrm{O}_{3}$ series oxides, J. Electrochem. Soc., 127:2360-2364. https://doi.org/10.11 49/1. 2129415.

4. Yamada S., Matsumoto Y., Sato E. (1981). Oxygen Evolution on $\mathrm{La}_{1-\mathrm{x}} \mathrm{Sr}_{\mathrm{x}} \mathrm{Fe}_{1-\mathrm{y}} \mathrm{Ni}_{\mathrm{y}} \mathrm{O}_{3}$ Series Oxides, The journal of the Electrochemical Society of Japan, 49:269273. https://doi.org/10.5796/kogyobutsurikagaku.49.269

5. Kobussen A.G.C., Willems H., Broers G.H.J. (1982). The oxygen evolution on $\mathrm{La}_{0.5} \mathrm{Ba}_{0.5} \mathrm{CoO}_{3}$ : Passivation processes, J. Electroanalytical Chemistry and Interfacial Electrochemistry 142:85-94. https://doi.org/10.1016/S00 22-0728(82)80007-7

6. Bockris J. O’M, Otagawa T., Young V. (1983). Solid state surface studies of the electrocatalysis of oxygen evolution on perovskites, J. Electroanal. Chem., 150:633-643. https://doi.org/10.1016/S0022-0728(83)80243-5.

7. Shimizu Y., Matsuda H., Miura N., Yamazoe N. (1992). Bifunctional Oxygen Electrode Using Large Surface Area Perovskite-type Oxide Catalyst for Rechargeable MetalAir Batteries, Chem. Lett., 21:1033-1036. https://doi.org/ 10.1246/cl.1992.1033.

8. Schmidt T., Wendt H. (1994). Electrocatalysis of cathodic hydrogen and anodic oxygen evolution in alkaline water electrolysis by in situ activation procedures, Electrochim. Acta., 39:1763-1767. https://doi.org/10.1016/00134686 (94)85162-X.

9. Tiwari S. K., Chartier P., Singh R. N.(1995). Preparation of Perovskite-Type Oxides of Cobalt by the Malic Acid Aided Process and Their Electrocatalytic Surface Properties in Relation to Oxygen Evolution, J. Electrochem. Soc., 143:148-153. https://doi.org/10.1149/1.2043854.

10. Jain A. N., Tiwari S. K., Singh R. N. Chartier P. (1995). Low-temperature synthesis of perovskite-type oxides of lanthanum and cobalt and their electrocatalytic properties for oxygen evolution in alkaline solutions, J. Chem. Soc. Faraday Trans., 91:1871-1875. https://doi.org/10.1039/FT 9959101871.

11. Singh R. N., Bahadur L., Pandey J. P., Singh S. P., Chartier P., Poillerat G. (1994). Preparation and characterization of thin films of $\mathrm{LaNiO}_{3}$ for anode application in alkaline water electrolysis, J. Appl. Electrochem., 24:149-156. https://doi.org/10.1007/BF00247787.

12. Singh S. P., Singh R. N., Poillerat G., Chartier P. (1995), Physicochemical and electrochemical characterization of active films of $\mathrm{LaNiO}_{3}$ for use as anode in alkaline water electrolysis, Int. J. Hydrogen Energy, 20:203-210. https://doi.org/10.1016/0360-3199(94)E0027-V.

13. Singh R. N., Jain A. N., Tiwari S. K., Poillerat G., Chartier P. (1995). Physicochemical and electrocatalytic properties 
of $\mathrm{LaNiO}_{3}$ prepared by a low-temperature route for anode application in alkaline water electrolysis., J. Appl. Electrochem., 25:1133-1138. https://doi.org/10.1007/BF00 242541.

14. Tiwari S. K., Koenig J. F., Poillerat G., Chartier P., Singh R. N. (1998). Electrocatalysis of oxygen evolution/ reductionon $\mathrm{LaNiO}_{3}$ prepared by a novel malic acid-aided method, J. Appl. Electrochem., 28:114-119. https://doi.org/ 10.1023/A:1003214321780.

15. Singh R. N., Tiwari S. K., Singh S. P., Singh N. K., Poillearat G., Chartier P. (1996). Synthesis of (La, Sr) $\mathrm{CoO}_{3}$ perovskite films via a sol-gel route and their physicochemical and electrochemical surface characterization for anode application in alkaline water electrolysis, J. Chem. Soc. Faraday Trans., 92(14):25932597. https://doi.org/10.1039/FT9969202593.

16. Singh R. N., Tiwari S. K., Singh S. P., Jain A. N., Singh N. K. (1997). Electrocatalytic activity of high specific surface area perovskite-type $\mathrm{LaNiO}_{3}$ via sol-gel route for electrolytic oxygen evolution in alkaline solution, Int. J. Hydrogen Energy, 22:557-562. https://doi.org/10.1016/ S0360-3199(96)00176-0.

17. Sharma T., Singh N. K., Tiwari S. K., Singh R. N. (1998). Electrocatalytic properties of La-manganites prepared by low temperature synthesis, Ind. J. Engg. \& Mat. Sci., 5:3842.

18. Singh N. K., Tiwari S. K., Singh R. N. (1998). Electrocatalytic properties of lanthanum manganites obtained by a novel malic acid-aided route, Int. J. Hydrogen Energy, 23:775-780. https://doi.org/10.1016/ S0360-3199(97)00119-5.

19. Lal B., Singh N. K., Singh R. N. (2001). Electrocatalytic properties of Sr-doped $\mathrm{LaMnO}_{3}$ obtained by a new sol-gel route in relation to $\mathrm{O}_{2}$ evolution in alkaline solution, Ind. J. Chem., 40 A:1269-1276.

20. Singh N. K., Lal B., Singh R. N. (2002). Electrocatalytic properties of perovskite-type $\mathrm{La}_{1-\mathrm{x}} \mathrm{Sr}_{\mathrm{x}} \mathrm{MnO}_{3}$ obtained by a novel sol-gel route for $\mathrm{O}_{2}$ evolution in $\mathrm{KOH}$ solutions, Int. J. Hydrogen Energy, 27:885-893. https://doi.org/10.1016/ S0360-3199(02)00008-3.

21. Lal B., Raghunanda M. K., Gupta M., Singh R. N. (2005). Electrocatalytic properties of $\mathrm{La}_{1-\mathrm{x}} \mathrm{Sr}_{\mathrm{x}} \mathrm{CoO}_{3}(0 \leq \mathrm{x} \leq 0.4)$ perovskite-type obtained by a novel stearic acid sol-gel method for electrocatalysis of $\mathrm{O}_{2}$ evolution in $\mathrm{KOH}$ solutions Int. J. Hydrogen Energy, 30:723-729. https://doi.org/10.1016/j.ijhydene.2004.07.002.

22. Suntivich J., Gasteiger H. A., Yabuuchi N., Nakanish H., Goodenough J. B., Shao-Horn Y. (2011). Design principles for oxygen-reduction activity on perovskite oxide catalysts for fuel cells and metal-air batteries, Nature Chemistry, 3:546-550. https://doi.org/10.1038/nchem.1069

23. Sunarso J., Torriero A. A. J., Zhou W., Howlett P. C., Forsyth M. (2012). Oxygen Reduction Reaction Activity of La-Based Perovskite Oxides in Alkaline Medium: A Thin-Film Rotating Ring-Disk Electrode Study, J. Phys. Chem., 116:5827-5834. https://doi.org/10.1021/jp211946n.

24. Yadav M. K., Yadav Ritu, Sharma Priya, Singh N. K. (2016). Synthesis and electrocatalytic properties of $\mathrm{La}_{1}$ ${ }_{x} \mathrm{Sr}_{\mathrm{x}} \mathrm{CoO}_{3}(0 \leq \mathrm{x} \leq 0.8)$ film electrodes for oxygen evolution in alkaline solutions, Int. J. Electrochem. Sci., 11:8633 8645. doi: 10.20964/2016.10.01.

25. Singh N. K., Yadav M. K., Fernandez C. (2017). Electrocatalytic properties of $\mathrm{La}_{1-\mathrm{x}} \mathrm{Cu}_{\mathrm{x}} \mathrm{CoO}_{3}(0 \leq \mathrm{X} \leq 0.8)$ film electrodes prepared by malic acid sol-gel method at $\mathrm{pH}=3.75$, Int. J. Electrochem Sci., 12:7128-7141. doi: 10.20964/2017.08.68.

26. Singh N. K., Sharma P., Kumar I., Chaddha A. S. (2019). Oxygen evolution electrocatalytic properties of perovskitetype $\mathrm{La}_{1-\mathrm{x}} \mathrm{Sr}_{\mathrm{x}} \mathrm{CoO}_{3}(0 \leq \mathrm{x} \leq 0.8)$ oxides obtained by polyvinylpyrrolidone sol-gel route, Int. J. Electrochem. Sci., 14:11379-11390. doi: 10.20964/2019.12.70.

27. Singh N. K., Sharma P., Yadav M. K., Parihar R. (2020). Oxygen evolution electrocatalytic properties of perovskitetype oxides obtained by PVP sol-gel route: Part II. The effect of partial substitution of $\mathrm{Sm}$ for $\mathrm{Sr}$ in $\mathrm{La}_{0.4} \mathrm{Sr}_{0.6} \mathrm{CoO}_{3}$, Int. J. Electrochem. Sci., 15:7001-7012. doi:10.20964 /2020.07.81.

28. Shin Boyoon, Choi Sangwon, Tak Yongsug (2016). Electrocatalytic Activity of Co-based Perovskite Oxides for Oxygen Reduction and Evolution Reactions, Int. J. Electrochem. Sci., 11:5900-5908, https://doi.org/10.20964/ 2016.07.68

29. Zhang Z., Zhou D., Wu X., Bao X., Liao J., Wen M. 2019). Synthesis of $\mathrm{La}_{0.2} \mathrm{Sr}_{0.8} \mathrm{CoO}_{3}$ and its electrocatalytic activity for oxygen evolution reaction in alkaline solution, Int. J. Hydrogen Energy, 44:7222-7227, https://doi.org/10.1016/ j.ijhydene.2019.01.268

30. Singh R. N., Lal B. (2002). High surface area lanthanum cobaltate and its A and B sites substituted derivatives for electrocatalysis of $\mathrm{O}_{2}$ evolution in alkaline solution, Int. J. Hydrogen Energy, 27:445-46, https://doi.org/10.1016/S0 360-3199(01)00078-7

31. Tseung A. C. C., Bevan H. L. (1973). A reversible oxygen electrode, J. Electroanal. Chem., 45:429-438. https://doi. org/10.1016/S0022-0728(73)80053-1.

32. Matsuki K., Kamada H. (1985). Research on Energy Conversion and Storage Through Chemical Process, SPEY, vol. 13 p. 181

33. Bockris J. O. M., Otagawa T. (1984). The Electrocatalysis of oxygen evolution on perovskites, J. Electrochem. Soc., 131: 290-302. https://doi.org/10.1149/1.2115565.

34. Balej J. (1985). Electrocatalysts for oxygen evolution in advanced water electrolysis, Int. J. Hydrogen Energy, 10:89-99. https://doi.org/10.1016/0360-3199(85)90041-2.

35. Kobussen A. G. C., Buren van F. R., Den Belt van T. G. M., Wees van H. J. A. (1979). Oxygen evolution on $\mathrm{LaCoO}_{3}-$ type electrodes, J. Electroanal Chem., 96:123-125.

36. Matsumoto Y., Manabe H., Sato E. (1980). Oxygen evolution on $\mathrm{La}_{1-\mathrm{x}} \mathrm{Sr}_{\mathrm{x}} \mathrm{CoO}_{3}$ electrodes in alkaline solutions, J. Electrochem Soc. 127:811-814. https:// doi.org/10.1149/1.2129762

37. Wendt H., Plzak V. (1983). Electrocatalytic and thermal activation of anodic oxygen- and cathodic hydrogenevolution in alkaline water electrolysis, Electrochim Acta, 28:27-34. https://doi.org/10.1016/0013-4686(83)85083-X.

38. Fiori G., Mari C. M. (1982). Electrocatalysis of oxygen evolution, Int. J. Hydrogen Energy, 7:489-493. https://doi.org/10.1016/0360-3199(82)90106-9.

39. Vidyasagar K., Gopalkrishnan J., Rao C.N.R. (1985). Synthesis of complex metal oxides using hydroxide, cyanide, and nitrate solid solution precursors, J. Solid state chem., 58:29-37. https://doi.org/10.1016/0022-4596(85) 90266-X

40. Vassiliou J. K., Hornbostel M., Ziebarth R., Disalvo F. J. (1989). Synthesis and properties of $\mathrm{NdNiO}_{3}$ prepared by 
low-temperature methods, J. Solid State Chem., 81:208216. https://doi.org/10.1016/0022-4596(89)90008-X

41. Teraoka Y., Kakebayashi H., Moriguchi I., Kagawa S. (1991). Hydroxy acid-aided synthesis of perovskite-type oxides of cobalt and manganese, Chemistry Letters, 20:673-676. https://doi.org/10.1246/cl.1991.673

42. Taguchi H., Yoshioka H., Matsuda D., Nagao M. (1993). Crystal structure of $\mathrm{LaMnO}_{3+\delta}$ synthesized using poly (acrylic acid), Solid State Chem., 104:460-463. https://doi.org/10.1006/jssc.1993.1181.

43. Nagai T., Fujiwara N., Asahi M., Yamazaki Shin-Ichi, Siroma Z., Ioroi T. (2014). Synthesis of nano-sized perovskite-type oxide with the use of polyvinyl pyrrolidone, J. Asian Ceramic Society, 2:329-332. https://doi.org/10.1016/j.jascer.2014.08.004

44. Azad Uday Pratap, Singh Monika, Ghosh Sourav, Singh Ashish Kumar, Ganesan Vellaichamy, Singh Akhilesh Kumar, Prakash Rajiv (2018). Facile synthesis of BSCF perovskite oxide as an efficient bifunctional oxygen electrocatalyst, Int. J. Hydrogen Energy, 43:20671-20679. https://doi.org/10.1016/j.ijhydene.2018.09.134

45. Gozzo C. B., Mario R. S. Soares, Sczancoski J. C., Nogueira I. C. , Edson R. Leite. (2019). Investigation of the electrocatalytic performance for oxygen evolution reaction of Fe-doped lanthanum nickelate deposited on pyrolytic graphite sheets Int. J. Hydrogen Energy, 39:21659-21672. https://doi.org/10.1016/j.ijhydene.2019. 06.109

46. Grimaud Alexis, May Kevin J., Carlton Christopher E., Lee Yueh-Lin, Risch Marcel, Hong Wesley T., Zhou Jigang, Shao-Horn Y. (2013). Double perovskites as a family of highly active catalysts for oxygen evolution in alkaline solution, Nature Communications, 4:1-7. https://doi.org/10. 1038/ncomms3439.

47. Fradette N., Marsan B. (1998). Surface studies of $\mathrm{Cu}_{\mathrm{x}} \mathrm{Co}_{3}$ ${ }_{\mathrm{x}} \mathrm{O}_{4}$ electrodes for the electrocatalysis of oxygen evolution, J. Electrochem. Soc., 145:2320-2327, https://doi.org/10. 1149/1.1838637.

48. Singh R. N., Pandey J. P., Anitha K. L. (1993). Preparation of electrodeposited thin films of nickel-iron alloys on mild steel for alkaline water electrolysis. Part I: studies on oxygen evolution, Int. J. Hydrogen Energy, 18:467-473. https://doi.org/10.1016/0360-3199(93)90002-R

49. Singh N. K., Tiwari S. K., Anitha K. L., Singh R. N. (1996). Electrocatalytic properties of spinel-type $\mathrm{Mn}_{\mathrm{x}} \mathrm{Fe}_{3-\mathrm{x}} \mathrm{O}_{4}$ synthesized below $100^{\circ} \mathrm{C}$ for oxygen evolution in $\mathrm{KOH}$ solutions, J. Chem. Soc. Faraday Trans., 92(13):2397-2400. https://doi.org/10.1039/FT9969202397.

50. Wu Wei, Guo Shaoqiang, Zhang Jinsuo (2018). Electrochemical Behaviors of $\mathrm{Cr}(\mathrm{III})$ in Molten LiF-NaFKF Eutectic, Int. J. Electrochem. Sci., 13:225-234. doi: 10.20964/2018.01.21.

51. Massot L., Chamelot P., Cassayre L., Taxil P. (2009). Electrochemical study of the $\mathrm{Eu}(\mathrm{III}) / \mathrm{Eu}(\mathrm{II})$ system in molten fluoride media, Electrochim Acta, 54:6361-6366. https://doi.org/10.1016/j.electacta.2009.06.016.

52. Bard A. J., Faulkner L. R. (2001). Electrochemical Methods: Principles and Applications, 2nd ed., Wiley, New York.

53. Gileadi E. (1993). Electrode Kinetics, (VCH Publishers Inc., New York), p.151.

54. Singh R. N., Pandey J. P., Singh N. K., Lal B., Chartier P., Koenig J. F. (2000). Sol-gel derived spinel $\mathrm{M}_{\mathrm{x}} \mathrm{Co}_{3-\mathrm{x}} \mathrm{O}_{4}(\mathrm{M}$
$=\mathrm{Ni}, \mathrm{Cu} ; 0 \leq \mathrm{x} \leq 1)$ films and oxygen evolution, Electrochim Acta, 45:1911-1919, https://doi.org/10.1016 /S00134686 (99)00413-2 